\title{
Variation of the Chemical Element Content in the Dealu Bujorului Vineyard Soil
}

\author{
Florin Dumitru BORA ${ }^{1}$, Alina DONICI ${ }^{1}$, Elena POSTOLACHE ${ }^{1}$, Aurel CIUBUCA ${ }^{1}$, Viorica ENACHE ${ }^{1}$, Gabriel \\ TABARANU ${ }^{1}$, Nicolaie BÎRLIGA ${ }^{1}$, Ionut RACZ ${ }^{2}$, Claudiu Ioan BUNEA ${ }^{3 *}$ \\ ${ }^{1}$ Department of Physico-Chemistry and Biochemistry, Research Station for Viticulture and Enology \\ Târgu Bujoru, Romania \\ 2 Wheat Breeding Department, Agricultural Research and Development Station Turda, Romania \\ 3 Department of Horticulture and Landscape, University of Agricultural Sciences and Veterinary \\ Medicine, Cluj-Napoca, Romania \\ *corresponding author: claus_bunea@yahoo.com
}

Bulletin UASVM Horticulture 75(2) / 2018

Print ISSN 1843-5262, Electronic ISSN 1843-536X

DOI:10.15835/buasvmcn-hort: 2018.0010

\begin{abstract}
The purpose of this study is to know better the concentration of chemical elements in the soil from Dealu Bujorului vineyard. The determination of the ten elements from the soil samples was performed using ICP-MS. The results showed diverse patterns of cadmium, lead, uranium, mercury, arsenic, strontium, cobalt, copper, nickel and chromium, all the elemental content studied were under the maximum limit admitted, except for copper (average $356.03 \mathrm{mg} / \mathrm{kg}$ while M.L.A. $=20 \mathrm{mg} / \mathrm{kg}$ ).
\end{abstract}

Keywords: Dealu Bujorului vineyard, elemental concentration, vineyard soil

\section{Introduction}

In modern ecology, soil pollution is any action which results in disruption of the normal operation of the soil (Bora et al., 2015). Appearance of the elements in vineyard soil could be attributted to the application of organic and mineral fertilizers, inorganic pesticides and other substance used in growing practices. Phosphatic fertilizers has higher concentration of $\mathrm{Cd}$ compared with other fertilizers (Ramachandran and D'Souza, 1998). Also, pesticides may increase the contents of $\mathrm{Cu}$, As and $\mathrm{Zn}$. Environmental pollution was not directly associated with viticulture practice. This source is mainly related to suspend particular matter or natural pollution, leading to an increase of lithophile elements (Al, Mn, Sr, Ti) or of anthropogenic origin, leading to higher flux of volatile elements ( $\mathrm{Cd}, \mathrm{Ni}, \mathrm{Pb}, \mathrm{V}$ and $\mathrm{Zn}$ ). Various soil properties, e.g. organic matter content, can have a strong influence on progressive transition metal accumulation (Alloway, 1990). It is well known that metals in low contents such as $\mathrm{Cu}, \mathrm{Zn}, \mathrm{Mo}$ and $\mathrm{Mn}$ are essential for plant growth (Marschner, 1995), but they have also adverse effects on growth, therefore is necessary to improve our knowledge of the influence of contaminated soil on the grapevine growth (Frías et al., 2001; Jakubowski et al., 1999; Kment et al., 2005).

\section{Materials and methods}

Soil samples were harvested from Dealu Bujorului vineyard $\left(45^{\circ} 52^{\prime} 10^{\prime \prime} \mathrm{N}, 2^{\circ} 55^{\prime} 8^{\prime \prime} \mathrm{E}\right)$, the scattered spreading territory of this vineyard corresponds almost entirely to the geographical subunit known as Colinele Covurluiului, in these area is also located the Dealu Bujorului vineyard. The vineyard is crossed by the parallel $46^{\circ}$ latitude north, intersected by the $28^{\circ}$ longitude meridian. 
Dealu Bujorului vineyard belongs to Galați country. The specificity of the transition area is highlighted by the predominance of deposits of clays and sands. Versants were made from clay deposits and sandy sands.

Soil samples (3 samples / depth) were collected from 10 in $10 \mathrm{~cm}$ to a depth of $120 \mathrm{~cm}$. Ecopedological conditions of Dealu Bujorului vineyard are presented in Blaga et al. (2005) and Toti et al. (2017). Soil samples were collected using stainless steel shovels and were stored in individual black plastic bags (darkness). All samples were taken in triplicates from the defined experimental plot.

Soil samples have been brought first to sandsize material $(<2 \mathrm{~mm})$ using a jaw crusher then mechanically split to obtain a representative samples and eventually pulverized to powder-size, grain-size smaller than $100 \mu$ ( $<400$ mesh), using a ball mill. Agate ball mill is used in place of any other pulverization metal device to avoid possible trace element contamination.

For the determination of elemental concentration from soils, there were used $0.5 \mathrm{~mL}$ soil and adjust with $8 \mathrm{~mL}\left(7 \mathrm{~mL} \mathrm{HNO}_{3} 65 \%+1 \mathrm{~mL}\right.$ $\mathrm{H}_{2} \mathrm{O}_{2}$ ), after 15-30 minutes the mineralization was performed using a microwave system Milestone START D Microwave Digestion System set in three steps: step I (time $10 \mathrm{~min}$., temperature $220^{\circ} \mathrm{C}$ ), step II (time $15 \mathrm{~min}$. , temperature $220^{\circ} \mathrm{C}$ ) and step III (time $60 \mathrm{~min}$., ventilation temperature $35^{\circ} \mathrm{C}$ ). The analysis was made using multielement analysis and ICP-MS technique, after an appropriate dilution, using external standard calibration method. The calibration was performed using XXICertiPUR multielement standard and from individual standard solution of $\mathrm{Cr}$ and $\mathrm{Hg}$. The determination methods for elements concentration from soils was optimized in a previous work (Bora et al., 2018).

The aim of this study is to obtain the overview on elemental concentration from Dealu Bujorului vineyard soil.

\section{Results and discussions}

Regarding the concentration of elemental content from Dealu Bujorului vineyard soil, the highest concentrations were recorded on surface of the soil profile [ $\mathrm{Cu} 527.35 \pm 3.29 \mathrm{mg} / \mathrm{kg}(0-10$ $\mathrm{cm}) ; 525.27 \pm 6.05(10-20 \mathrm{~cm}) \mathrm{mg} / \mathrm{kg})$ and $\mathrm{Cr}$ $14.13 \pm 0.76 \mathrm{mg} / \mathrm{kg}(30-40) ; 13.42 \pm 0.25 \mathrm{mg} / \mathrm{kg}$
(20-30 cm)] but these concentrations decrease with increasing depth of the soil profile [Cu 313.66 $\pm 3.78 \mathrm{mg} / \mathrm{kg}(100-110 \mathrm{~cm}) ; 222.55 \pm 11.35$ (110$120 \mathrm{~cm}) \mathrm{mg} / \mathrm{kg})$ and $\mathrm{Cr} 8.91 \pm 0.40 \mathrm{mg} / \mathrm{kg}(110-$ $120 \mathrm{~cm}$ )]. Exception to this rule is As: increasing the depth of the soil profile also increases the concentration of it in vineyard soil [Pb $0.47 \pm 0.05$ $\mathrm{mg} / \mathrm{kg}(0-10 \mathrm{~cm}) ; 0.54 \pm 0.04(10-20 \mathrm{~cm}) \mathrm{mg} / \mathrm{kg})]$; if the depth of the soil profile is from $100-120 \mathrm{~cm}$ than the concentration decreases [As $1.33 \pm 0.02$ $\mathrm{mg} / \mathrm{kg}(100-110 \mathrm{~cm}) ; 1.22 \pm 0.15 \mathrm{mg} / \mathrm{kg}(110-$ $120 \mathrm{~cm})]$. The data showed high concentration of $\mathrm{Cu}$ in Dealu Bujorului vineyard soil. This metal concentration in the topsoil of Dealu Bujorului vineyard plots significantly surpass the maximum values reported in literature $1500 \mathrm{mg} / \mathrm{kg}$ (FloresVeles et al., 1996). The copper enrichement in different vineyard soil types reflects the period of copper-based pesticide application (Flores-Veles et al., 1996).

The results obtained are comparable to those obtained by Albulescu et al. (2009) 1.77 [Cd (mg/ $\mathrm{kg})], 21.63[\mathrm{~Pb}(\mathrm{mg} / \mathrm{kg})], 24.55$ [Ni $(\mathrm{mg} / \mathrm{kg})]$, 13.32 [Cr (mg/kg)]; Alagić et al. (2014) $3.14 \pm$ 0.03 [Cd (mg/kg)], 42.80 [Pb (mg/kg)], $10.70 \pm$ 0.01 [As (mg/kg)], 293.00 [Cu (mg/kg)] but also Bravo et al. (2017) $16.18 \pm 5.20[\mathrm{~Pb}(\mathrm{mg} / \mathrm{kg})]$, $241.88 \pm 493.40[\mathrm{Sr}(\mathrm{mg} / \mathrm{kg})], 10.87 \pm 5.10[\mathrm{Cu}$ $(\mathrm{mg} / \mathrm{kg})]$. Regaring the results obtained by Huzum et al., 2012 background area (Huși area) there were higher [22.90 Pb (mg/kg), $13.20 \mathrm{As}(\mathrm{mg} /$ $\mathrm{kg}), 14.00$ Co (mg/kg), $45.00 \mathrm{Ni} \mathrm{(mg/kg),} 140.00$ $\mathrm{Cr}(\mathrm{mg} / \mathrm{kg})]$ compared with the results obtained in thgis study [7.00 Pb (mg/Kg), $1.29 \mathrm{As}(\mathrm{mg} / \mathrm{Kg})$, 3.76 Co (mg/kg), $5.68 \mathrm{Ni}(\mathrm{mg} / \mathrm{kg}), 11.04 \mathrm{Cr}(\mathrm{mg} /$ $\mathrm{kg})]$ exception does $\mathrm{Cd} 0.19 \mathrm{Cd}(\mathrm{mg} / \mathrm{kg}$ ) (Huzum et al., 2012) - $0.37 \mathrm{Cd} \mathrm{mg/kg}$ and also $\mathrm{Cu} 79.30$ $\mathrm{Cu}$ (mg/kg) (Huzum et al., 2012) - $356.03 \mathrm{Cu}$ (mg/ $\mathrm{kg})$.

\section{Conclusions}

The results of this study showed diverse patterns of Cd (average $0.37 \mathrm{mg} / \mathrm{kg}$ while M.L.A. (Maximum Admissible Limit) $=1 \mathrm{mg} / \mathrm{kg}$ ), Pb (average $7.00 \mathrm{mg} / \mathrm{kg}$ while M.L.A. $=20.00 \mathrm{mg} / \mathrm{kg}$ ), $\mathrm{U}$ (average $0.36 \mathrm{mg} / \mathrm{kg}$ ), $\mathrm{Hg}$ (average $0.1 \mathrm{mg} / \mathrm{kg}$ while M.L.A. $=20.00 \mathrm{mg} / \mathrm{kg}$ ), As (average $1.29 \mathrm{mg} /$ $\mathrm{kg}$ while M.L.A. $=5.00 \mathrm{mg} / \mathrm{kg}$ ), $\mathrm{Sr}$ (average 36.35 $\mathrm{mg} / \mathrm{kg}$ ), Co (average $3.73 \mathrm{mg} / \mathrm{kg}$ while M.L.A. $=15.00 \mathrm{mg} / \mathrm{kg}$ ), Ni (average $5.68 \mathrm{mg} / \mathrm{kg}$ while M.L.A. $=20.00 \mathrm{mg} / \mathrm{kg}$ ) and $\mathrm{Cr}$ (average $11.04 \mathrm{mg} /$ 


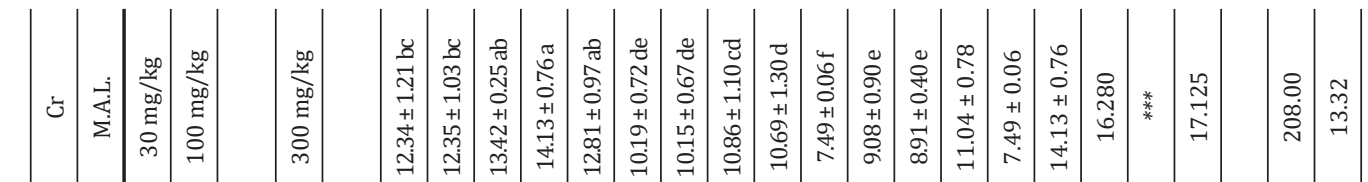

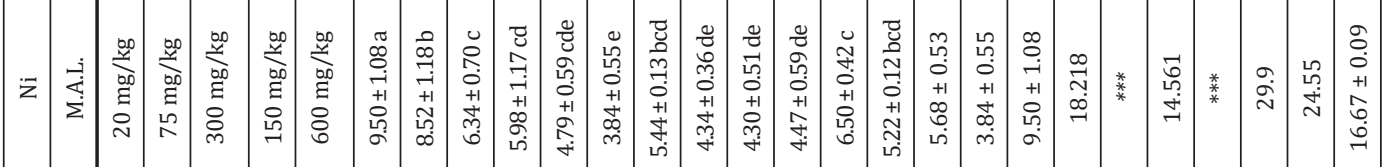

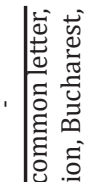

然.

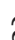

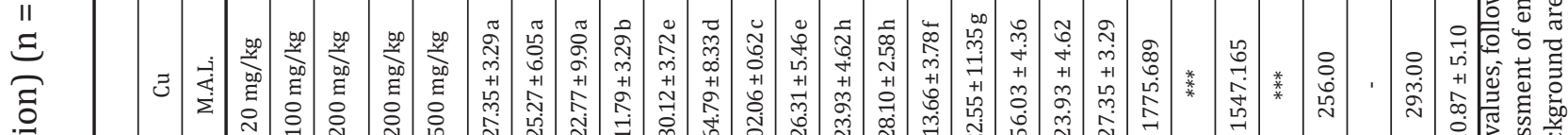

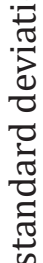

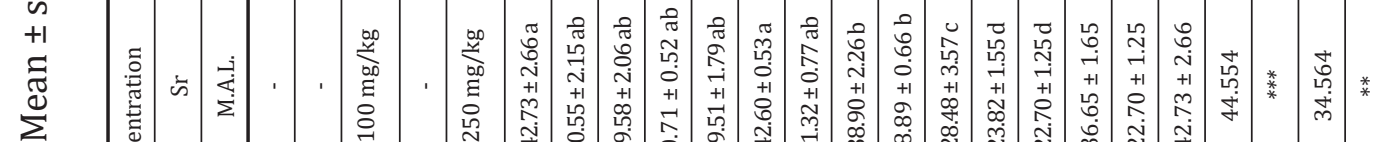

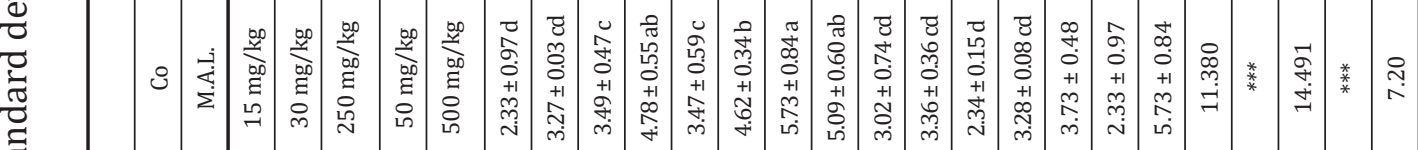

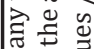

政。

잉

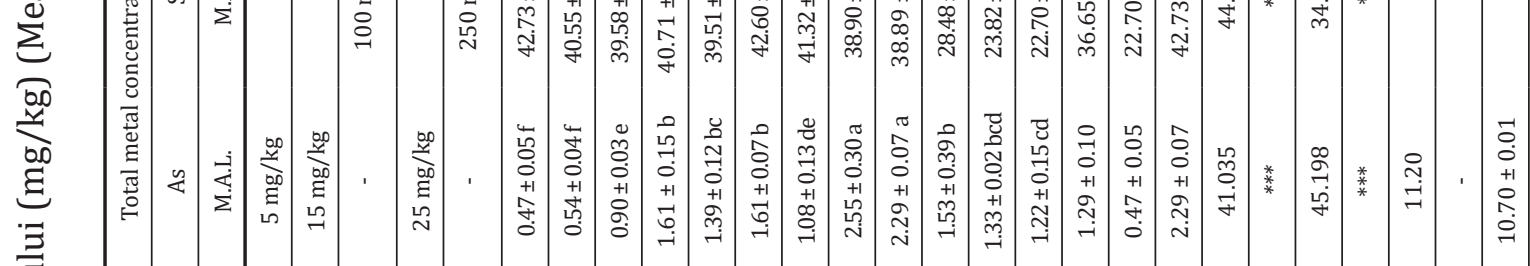

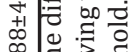

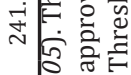

vi

o

竞

gृ

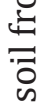

.

苋

(1)

西

咅

要

$\stackrel{\oplus}{ \pm}$

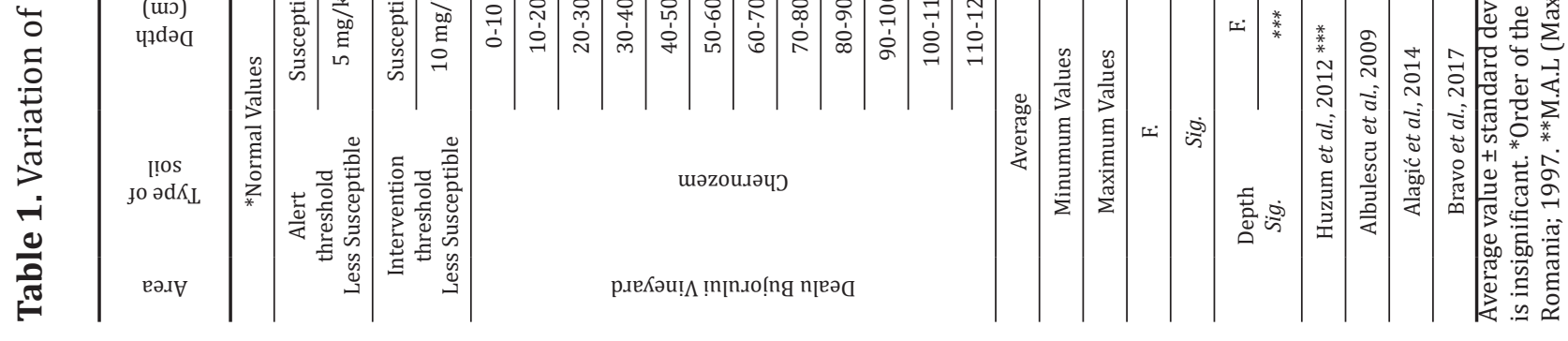

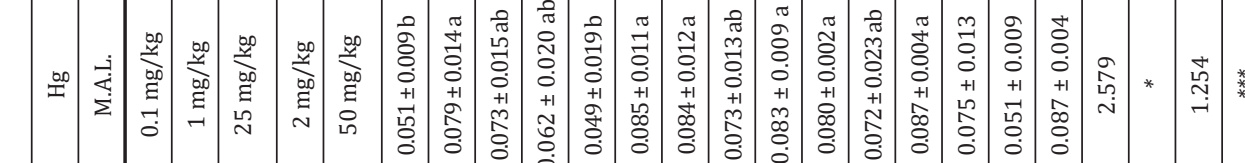

作

要

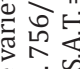

安

诺

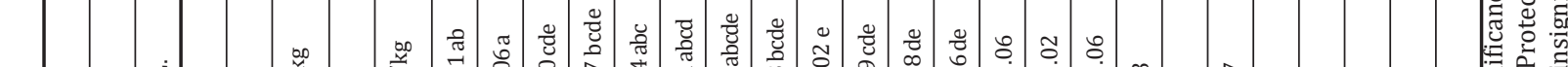

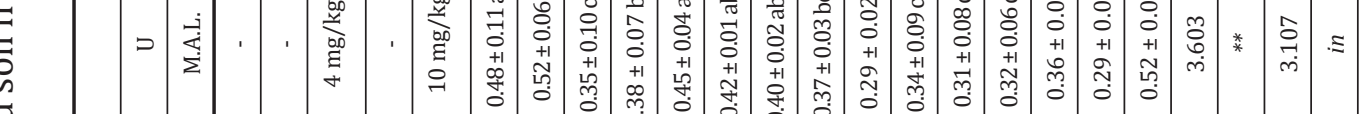

殹

象

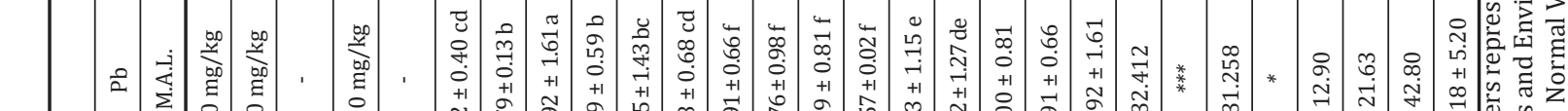

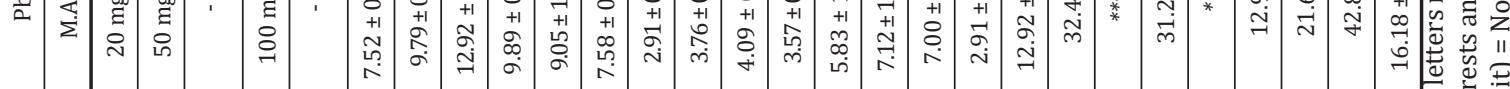

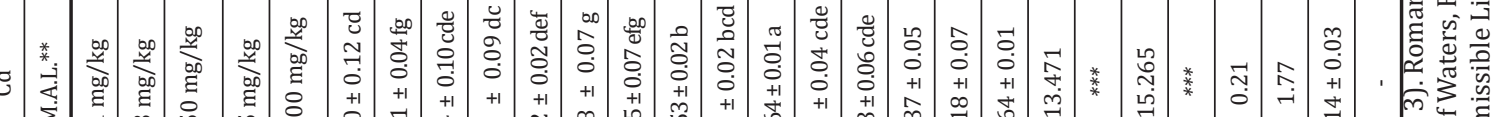

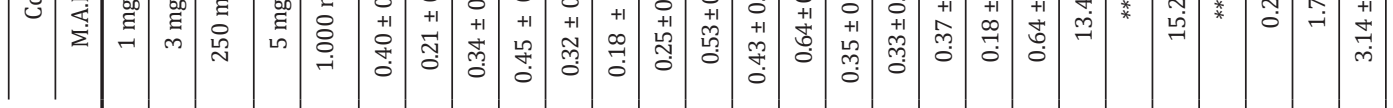

II

要要

(ш)

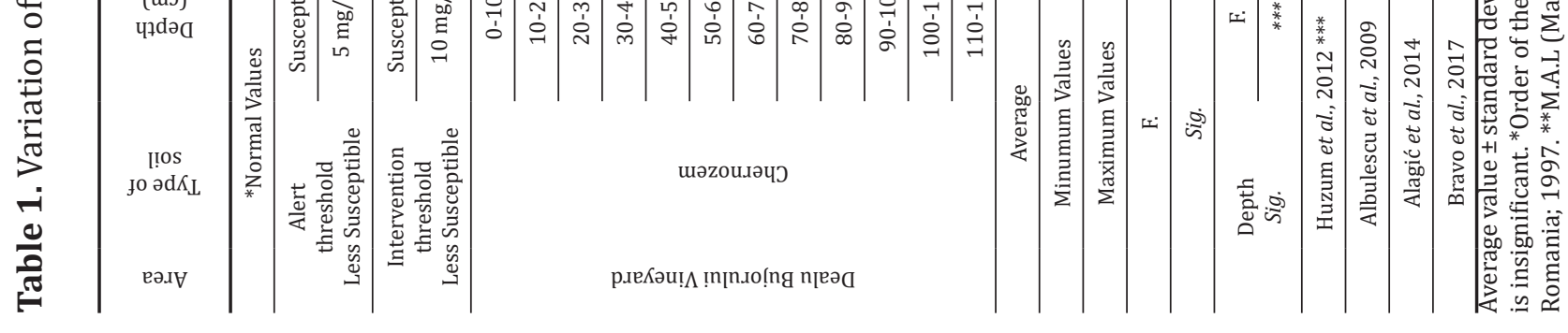


$\mathrm{kg}$ while M.L.A. $=30.00 \mathrm{mg} / \mathrm{kg}$ ), all the elemental studied were under the maximum limit admitted, except for $\mathrm{Cu}$ (average $356.03 \mathrm{mg} / \mathrm{kg}$ while M.L.A. $=20 \mathrm{mg} / \mathrm{kg}$; S.A.T. (Susceptible Alert Threshold) = $100 \mathrm{mg} / \mathrm{Kg}$ ). A possible explanation for the high concentration of $\mathrm{Cu}$ obtained was the application of different $\mathrm{Cu}$ formations against wide rage of insect pests and diseases during the time.

Acknowledgments. This paper was published under the frame of the Romanian Ministry of Agriculture and Rural Development, project ADER no. 14.2.2. "Quantitative studies on assessment and monitoring contaminants, on the chain of viticulture and winemaking to minimize the amount of pesticides and heavy metals as principal pollutants".

\section{References}

1. Albulescu M, Turuga L, Popovici H, Masu S, Uruioc S, Kiraly LZ (2009). Study regarding the heavy metals content (Lead, Nichel, Chromium, Cadmium) in soil and Vitis vinifera in vineyard from Caras-Severin Country. Annals of West Universty of Timisoara 18(3): 45-52.

2. Alagić SČ, Tošić DB, Dimitrijević MD, Nujkić MM (2014). Assessment of the quality of polluted areas based on the content of heavy metals in different organs of the grapevine (Vitis vinifera) cv Tamjanika. Environmental Science and Pollution Research, 22(9): 7155-7175.

3. Alloway BJ (1990). Heavy Metals in Soils. Blackie and Son, London: UK, (Chapter 3).

4. Bora FD, Bunea CI, Nastasia P (2015). Vertical distribution and analysis of micro-, macroelements and heavy metals in the system soil-grapevine-wine from North-West Romania. Chemistry Central Journal, 9(19): 1-13.

5. Bora FD, Donici A, Rusu T, Bunea A, Popescu D, Bunea CI (2018). Elemental profile and ${ }^{207} \mathrm{~Pb} /{ }^{206} \mathrm{~Pb},{ }^{208} \mathrm{~Pb} /{ }^{206} \mathrm{~Pb}$, ${ }^{204} \mathrm{~Pb} /{ }^{206} \mathrm{~Pb},{ }^{87} \mathrm{Sr} /{ }^{87} \mathrm{Sr}$ isotope ratio as fingerprints for geographical traceability of Romanian wines. Notulae
Botanicae Horti Agrobotanici Cluj-Napoca, 46(1): 223239.

6. Blaga G, Filipov F, Rusu I, Udrescu S, Vasile D (2004). Pedology. AcademicPress Cluj-Napoca, Romania (Chapter 14).

7. Bravo S, Amorós JA, Pérez-de-los-Reyes C, García FJ, Moreno MM, Sánchez-Ormeño M, Higueras P (2017). Influence of the soil $\mathrm{pH}$ in the uptake and bioaccumulation of heavy metals ( $\mathrm{Fe}, \mathrm{Zn}, \mathrm{Cu}, \mathrm{Pb}$ and $\mathrm{Mn}$ ) and other elements ( $\mathrm{Ca}, \mathrm{K}, \mathrm{Al}, \mathrm{Sr}$ and $\mathrm{Ba}$ ) in vine leaves, Castilla-La Mancha (Spain). Journal of Geochemical Exploration, 173: 79-83.

8. Flores-Veles LM, Ducaroir J, Jaunet AM, Robert M (1996). Study of the distribution of copper in an acid sandy vineyard soil by three different methods. European Journal of Soil Science, 47: 523-532

9. Frías S, Trujillo J P, Peña E M, Conde JE (2001). Classification and differentiation of bottled sweet wines of Canary Islands (Spain) by their metallic content. European Food Research Technology, 213(2): 145-149.

10. Huzum R, Iancu OG, Buzgar N (2012). Geochemical distribution od selected trace elements in yineyard soils from the Huși area, Romania. Carpathian Journal of Earth And Environmental Sciences, 7(3): 61-70.

11. Jakubowski N, Brandt R, Stuewer D, Eschnauer HR, Görtges S (1999). Analysis of wines by ICP-MS: Is the pattern of the rare earth elements a reliable fingerprint for the provenance? Fresenius Journal of Analytical Chemistry, 364(5): 424-428.

12. Kment P, Mihaljević M, Ettler V, Šebek O, Strnad L, Rohlová L (2005). Differentiation of Czech wines using multielement composition - A comparison with vineyard soil. Food Chemistry, 91: 157-165.

13. Marschner H (1995). Mineral Nutrition of Higher Plants. (3th ed.). Cambridge, Academic Press, (Chapter 11).

14. Ramachandran V, D'Souza TJ (1998). Plant uptake of cadmium, zinc and manganese in soils amended with sewage sludge and city compost. Bulletin of Environmental Contamination and Toxicology, 61(3), 347-354.

15. Toti M, Dumitru M, Vlad V, Calciu I (2017). Soil - a basic element of the "Terroir" concept. Terra Nostra, Iași, Romania (Chapter 4). 